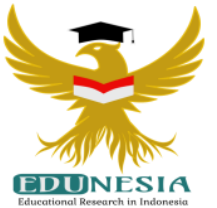

\title{
Development of LKPD Teaching Materials Based on Community Science Technology To Improve Students' High Level of Communication and Thinking Ability
}

\author{
Pihraf Risana1; Tri Jalmo2; Pujiati ${ }^{3}$; Dwi Yulianti4; ${ }^{4}$ Rochimayati ${ }^{5}$ \\ 1,2,3,4,5 Department of Primary Education, Universitas Lampung, Indonesia \\ ${ }^{1}$ Corresponding Email: msicha@gmail.com, Phone Number: 0896 xxxx xxxx
}

\section{Article History:}

Received: July 15, 2021

Revised: August 12, 2021

Accepted: August 24, 2021

Online First: August 28, 2021

Keywords:

Communication Skill,

Higher Order Thinking,

Ability,

LKPD,

STM-Based Learning,

Kata Kunci:

LKPD,

Pembelajaran Berbasis STM, Kemampuan Berkomunikasi, Kemampuan Berpikir Tingkat Tinggi.

\section{How to cite:}

Risana, P., Jalmo, T., Pujiati, P., Yulianti, D., \& Rochimayati, R. (2021). Development of LKPD Teaching Materials Based on Community Science Technology To Improve Students' High Level of Communication and Thinking Ability. Edunesia: Jurnal Ilmiah Pendidikan, 2 (3): 643-649.

This is an open access article under the $C C-B Y-N C$-ND license



Abstract: This development research aims to realize the development of STM-based LKPD, to find out the effect of developing STM-based LKPD which is theoretically feasible and suitable for use by educators in classroom learning. The research method used is development research (Research and Development) by using research steps according to Borg and Gall. The population in this study were fifth grade elementary school/MI educators in Rajabasa District, Bandar Lampung City, which amounted to eight educators. The sample used in this study was a saturated sample, namely eight educators. This study uses a qualitative descriptive analysis. Data collection techniques in this study were carried out in two ways, namely observation, and questionnaires (needs analysis questionnaire). The instruments in this study consisted of: 1) needs analysis instruments, 2) materials expert validation instruments, media experts and linguists, 3) user validation instruments (educators). The results of prototype product development were validated by material experts, media experts and linguists and validated by users, namely fifth grade educators at SD/MI Rajabasa District, Bandar Lampung City, totaling eight educators to support students' communication and high-level thinking skills in the learning process in the classroom.

Abstrak: Penelitian pengembangan ini bertujuan terwujudnya pengembangan LKPD berbasis STM, mengetahui pengaruh pengembangan LKPD berbasis STM yang layak secara teoritis dan layak digunakan oleh pendidik pada pembelajaran di kelas. Metode penelitian yang digunakan adalah penelitian pengembagan (Research and Development) dengan menggunakan langkah - langkah penelitian menurut Borg and Gall. Populasi dalam penelitian ini adalah pendidik kelas V SD/MI di Kecamatan Rajabasa Kota Bandar Lampung yang berjumlah delapan pendidik. Sampel yang digunakan dalam penelitian ini adalah sampel jenuh, yaitu delapan pendidik. Penelitian ini menggunakan analisis deskriptif kualitatif. Teknik pengumpulan data dalam penelitian ini dilakukan dengan dua cara, yaitu observasi, dan kuesioner (angket analisis kebutuhan). Instrumen dalam penelitian ini terdiri dari: 1) instrumen analisis kebutuhan, 2) instrumen validasi ahli materi, ahli media dan ahli bahasa, 3) instrumen validasi pengguna (pendidik). Hasil pengembangan produk prototipe divalidasi oleh ahli materi, ahli media dan ahli bahasa serta divalidasi oleh pengguna yaitu pendidik kelas V SD/MI Kecamatan Rajabasa Kota Bandar Lampung yang berjumlah delapan orang pendidik untuk mendukung kemampuan berkomunikasi dan berpikir tingkat tinggi peserta didik dalam proses pembelajaran di kelas. 


\section{A. Introduction}

Communication skills and higher order thinking skills (HOTS) are two key abilities to be able to compete in the 21st century and the industrial era 4.0. Therefore, currently the world of education, including in Indonesia, directs its goal to equip these two abilities to students. The birth of the 2013 curriculum which continues to be refined shows the seriousness of the Indonesian government to prepare a generation that is competitive at the national, regional and global levels (Kemal, et al, 2019).

The ability to communicate is a basic ability that must be possessed by a student. When in learning, students need communication skills to be able to assist and facilitate in expressing ideas, as well as exchanging information with teachers or fellow students. According to Resnick, as expressed by Heong (2011) high-level thinking is categorized as non-algorithmic, complex, meaningful, difficult, produces many solutions, full of assumptions, many criteria, and uncertain.

Learning activities are a process of communication. Communication in learning, the role of media or teaching materials is very important so that the message conveyed by the communicator can be received by the communicant effectively and efficiently (Priadi, 2020).

For this reason, media or teaching materials are needed that make it easier for teachers to convey the material (Gaol \& Sitepu, 2020). Teaching materials as an important component in the learning process. Teaching materials need to be designed according to the needs and characteristics of students in each educational unit, so that teachers are required to be able to make media teaching materials and be able to choose teaching materials that suit the needs and abilities of students.

Developing teaching materials should be an ability as a teacher (Sahudra, et al, 2021). Teaching materials are a very important component as a means of interaction between teachers and students. The habit of using handbooks for thematic subjects causes teachers to have difficulty or are not accustomed to compiling their own materials and teaching materials. Meanwhile, in the reality of education in the field, it can be seen that many educators still use conventional teaching materials, namely teaching materials that are left to use, just buy, and without any effort to plan, prepare, and arrange them themselves (Prastowo, 2013).

One of the impacts of the lack of varied teaching materials is that student participation in the learning process is still minimal due to student listening and writing activities (Bahruddin \& Febriani, 2020). Not all students want to listen to the teacher's explanation. Some students choose to talk alone with their friends. The efforts made by the teacher in the learning process at that time, the teacher must appoint students first and ask about the material being explained by the teacher. These efforts are made so that students pay more attention to the material presented by the teacher. One of the teaching materials that can be used for independent study is LKPD. The Student Activity Sheet (LKPD) is one of the learning resources that can be developed by educators as facilitators in learning activities.

Based on the results of the needs analysis questionnaire, $40 \%$ of teachers know about Community Science Technology, $40 \%$ of teachers have maximized their mastery of student material and overcome learning problems, but only $20 \%$ of teachers can cultivate higherorder thinking and communication skills in learning. All teachers have not implemented an STM-based learning approach and no teacher has developed an STM-based LKPD. LKPD developed by researchers is integrated with a learning approach that helps make it easier 
for students to understand the material. The learning approach chosen in the development of the LKPD is Community Science Technology (STM).

The selection of the STM approach in the development of LKPD is based on the fact that STM can guide students to be able to think globally or comprehensively and intact, and can solve environmental problems related to the community and participate in solving problems according to their capacity. STM-based thematic LKPD is a learning aid that is structured with the aim of opening students' horizons to be open to technology and providing views on the interrelationships of problems related to STM elements.

Based on the description above, the research objectives are formulated as follows, namely the realization of the development of STM-based LKPD, knowing the effect of developing STM-based LKPD, and knowing theeffectiveness of using STM-based LKPD to improve students' communication and high-level thinking skills.

\section{B. Method}

The research method used is research and development using research steps according to Borg and Gall (1983) which consists of 1) research and information gathering, 2) planning, 3) initial product development, 4) initial trials, 5) product revisions, 6) field trials, 7) product revisions, 8) field trials, 9) final product revisions, and 10) dissemination and implementation. The implementation of this research only reached the fifth step, namely product revision. This was done due to limitations in terms of time and cost as well as the current COVID-19 pandemic conditions. Product validation expert tests consist of linguists, material experts, and media experts.

The initial information collection was carried out using observation techniques and questionnaires (needs analysis questionnaires) to educators to find out an overview of the problems that became obstacles in the learning process. This stage is also a process for conducting needs assessment (needs analysis), identifying problems (needs), and conducting task analysis (task analysis). In this stage a needs analysis is carried out to gather information that it is necessary to develop an STM-based LKPD.

\section{Result and Discussion \\ Results of Needs Analysis}

Based on the results of a preliminary study in Rajabasa District, researchers obtained several problems in learning, namely based on the results of a needs analysis questionnaire showing $40 \%$ of educators know about Community Science Technology, $40 \%$ of educators have maximized their mastery of students' material and overcome learning problems, but only $20 \%$ of educators who can cultivate higher order thinking and communication skills in learning. All educators have not implemented an STM-based learning approach and no educator has developed an STM-based LKPD.

Based on the results of observations and questionnaire analysis of the need for teaching materials, the authors conclude that it is necessary to develop teaching materials that are able to overcome the problems of students on the Theme of Objects Around Us Subtheme of Single and Mixed Substances. Therefore, the authors develop teaching materials in the form of Student Worksheets (LKPD) based on STM on the Theme of Objects Around Us Sub-theme of Single and Mixed Substances. 


\section{Product Planning and Design Results}

Planning is a form of follow-up after conducting a needs analysis and identifying resources to meet needs. Steps in planning and designing products are carried out through several stages, namely: 1) preparation of the LKPD framework (outline); 2) preparation of LKPD needs map; 3) determine the title of the LKPD; 4) writing LKPD; and 5) develop LKPD assessment instruments.

Instructional analysis includes mapping of basic competencies and indicators in the developed sub-themes, as well as containing learning objectives which are descriptions of the indicators. Mapping of basic competencies and indicators is adjusted to those provided by the teacher's book and by developing indicators. Following up on the design that has been carried out in the product development plan stage, the following development steps are carried out; 1) pre-writing, namely the study of materials in the LKPD, carried out by collecting sources and references as well as pictures related to single and mixed objects; and 2) preparation of thedraft LKPD which includes aspects of content, presentation and graphic aspects.

The collection of materials that match the material is done by selecting and sorting the material so that it fits the needs. Materials are obtained from relevant book sources and pictures or photographs that are in accordance with the material.

\section{Preparation of LKPD}

Preparation of LKPD according to the draft which have been set. The components of the LKPD consist of: 1) cover page (cover); 2) author's page, 3) introduction, 4) table of contents, 5) general instructions for using LKPD, 6) core competencies, 7) mapping of basic competencies of KI 1 and 2,8) mapping of basic competencies of KI 3 and 4, 9) steps -learning steps, and 10) bibliography.

The cover page(cover)consists of 1) the title LKPD is "Worksheet Students Complement Based Science Technology Society, 2) the theme of 9 Museums Around Us and the subthemes that Subtheme 1 Benda's Singles and Mixed, 3) class and semester, Classroom V semester 2, 4) the author's name is Pihraf Risana, 5) supporting pictures illustrating various types of single and mixed substances.

Instructions for using LKPD consist of instructions for teachers and instructions for students. Instructions for teachers contain directions that must be carried out by teachers in learning using this LKPD, while instructions for students contain directions for students so that students find it easier to use the LKPD.

Mapping of basic competencies and indicators contains basic competencies and indicators in the content of lessons that are integrated in each lesson. This LKPD is organized into one sub-theme and consists of 6 lessons so that in this LKPD there are 6 mapping of basic competencies and indicators, starting from the 1st lesson to the 6th lesson. Learning objectives that contain the objectives to be achieved or competencies that will be possessed by students after carrying out learning activities with LKPD. The specified learning objectives refer to the learning indicators, there are 6 learning objectives according to the number of learnings in one sub-theme.

\section{The Results of The Expert Test on Materials, Language and Media}

The expert test is carried out so that the resulting product in the form of LKPD based on the STM approach on the Theme of Objects Around Us Sub-Theme of Single and Mixed 
Objects is appropriate and can be used by students. Validation was carried out by three experts, namely Dr. Pramudiyanti, M.Si. as a material expert, Dr. Mulyanto Widodo, M.Pd. as a linguist and Hermi Yanzi, M.Pd as a media expert. Validation was carried out by means of a questionnaire, using a Likert scale, besides that there was a suggestion column containing suggestions for improvements to the developed LKPD.

In the material expert test, the validator guides and directs the preparation of the LKPD in terms of material and the use of the STM approach. The material expert test on the LKPD is carried out once. In the material expert test, the score given by the validator is 84.90 . The suggestions that the validator gives are as follows, the questions made must refer to higher-order thinking, use components that refer to STM. Based on the suggestions given by the material experts above, the researchers made improvements to the LKPD that was developed. The improvements made were 1) correcting the form of questions that refer to improving communication skills and higher-order thinking, 2) integrating the components of the STM approach and 3) checking basic competencies, indicators, materials and evaluations so that they are synchronized.

In the media expert test, the validator guides and directs about 1) writing, 2) pictures, and 3) graphics (layout). In the expert design test, the score that the validator gave to the LKPD was 84.58 . The validator provides suggestions, namely the type of font that can be used at most is three types, the font size on the front cover must be large so that it is clearly legible, use contrasting colors on the cover to make it more attractive, use the original image on the cover.

In the linguistics test, the validator guides and directs about 1) the continuity of language use, 2) the suitability of language use with the level of development of students, and 3) the use of communicative language. In the linguistics test, the score that the validator gave to the LKPD was 83.33. The validator provides suggestions, namely the writing of letters and words/terms used in the LKPD.

\section{Discussion}

\section{Development of LKPD Based on STM}

Development of STM-based LKPD on the theme of objects around us sub-themes of single and mixed substances. The learning model used is STM which links the experience of students with new information or lessons learned at school.

The application of the STM approach to single and mixed objects is modified from (Poedjiadi, 2010) which consists of several steps, namely:

1. Exploration Stage

The exploration stage on single and mixed materials first discusses identifying examples of single and mixed substances in the surrounding environment correctly, correctly identifying the constituent substances of an object, mentioning and communicating advertising content, advertising meaning, meaning of foreign words in advertisements, observe the map of Indonesia and write down the names of the areas visited correctly, observe the map of the province of Lampung and identify the geographic location of the Lampung area, write down examples of behavior that reflect unity and integrity and examples of behavior that reflect unity and integrity. 
2. Concept Forming Process

In the process of concept development, students discuss in groups and communicate the results of the discussion. Previously the teacher had assigned each group to bring single and mixed objects and some examples of advertisements.

3. Concept Application Stage

Analyze issues or problems that have been raised at the beginning of learning based on concepts that have been understood previously. These stages include:

a) Application of Science

Application of science in this study discusses identifying single and mixed objects found in the surrounding environment, identifying the properties of mixtures and their constituent components.

b) Technology Applications Technological

applications include filtering cloudy water using used bottles, identifying the properties of mixtures in objects.

c) Environmental Applications Environmental

applications of the sub-themes of single and mixed objects in daily life include filtering cloudy water so that it can be reused. In order to filter water, simple tools and filters are used.

4. Concept Consolidation Stage

If during the concept formation process at this stage there are no misconceptions that occur in students, as well as after the end of the issue analysis and problem solving, educators still have to strengthen the concept. Concept stabilization is carried out by emphasizing key concepts that are important to know in certain study materials.

5. Assessment Stage Assessment

can be given in the form of a written test or an oral question. This stage ends a series of learning activities using the STM approach to reveal students' communication and higher-order thinking skills.

\section{Conclusion}

Based on the analysis of the results of research on the development of STM-based LKPD on the theme of Objects Around Us, the sub-themes of Single and Mixed Objects in class V SD/MI can be concluded as follows:

1. The process of developing LKPD based on Community Science Technology (STM) uses the Research and Development Borg model. and Gall through five development steps, namely: 1) research and information gathering, 2) planning, 3) initial product development, 4) preliminary testing, 5) major product revision.

2. STM-based LKPD get results that are suitable for use. The LKPD product feasibility test was tested by three validation experts consisting of, 84.58 media experts in the appropriate category, 84.90 material experts in the appropriate category, 83.33 linguists in the appropriate category. Based on the results of the questionnaire validation test of media experts, materials experts and linguists as well as expert practitioner responses, it was concluded that the STM-based research development worksheet for improving communication skills and higher-order thinking is theoretically feasible and suitable for 
use by users so that it can be applied to classroom learning.

\section{References}

Achmadi. (1996). Lembar Kerja Siswa. Bumi Aksara. Jakarta.

Bahruddin, U., \& Febriani, S. R. (2020). Student's perceptions of Arabic online learning during COVID-19 emergency. Journal for the Education of Gifted Young Scientists, 8(4), 1483-1492.

Gaol, R. L., \& Sitepu, A. (2020). The Influence of Used Good-Based Learning Media on the Value of Chracter Education and Student's Motivation to Study. Budapest International Research and Critics in Linguistics and Education (BirLE) Journal, 3(4), 16961703.

Hafied, C. (2018). Pengantar Ilmu Komunikasi. PT Raja Grafindo Persada. Jakarta.

Borg, W. \& Gall, M.D. (1983). Edication Reearch: An Introduction Fourth Edition. Longman. New York.

Heong, Y. M., Othman, W. B., Yunos, J. B. M., Kiong, T. T., Hassan, R. B., \& Mohamad, M. M. B. (2011). The level of marzano higher order thinking skills among technical education students. International Journal of Social Science and Humanity, 1(2), 121.

Kemal, I., Suryadi, S., Rosyidi, R., \& Unifah, U. (2019). Management of lecturers resources development at higher education. International Journal of Higher Education, 8 (5), pp. 246-256. https:// doi.org/10.5430/ijhe.v8n5p246.

Prastowo, A. (2013). Panduan Kreatif Membuat Bahan Ajar Inovatif. Diva Press. Yogyakarta.

Priadi, R. (2020). Teacher Communication Effectiveness in the Learning Process. Budapest International Research and Critics Institute (BIRCI-Journal): Humanities and Social Sciences, 3(4), 3433-3444.

Sahudra, T.M., Taher, A., \& Kemal, I. (2021). E-LearningDevelopment Management With The Schoology Improving Geographic Learning Literation. Journal of Edcucation Technology, 5 (1), pp. 70-7. http:/ / dx.doi.org/10.23887/jet.v5i1.33631. 